\title{
PENINGKATKAN KUALITAS HIDUP PASIEN KANKER DENGAN IMPLEMENTASI PERAWATAN KESEHATAN PSIKOSEKSUAL
}

\section{(Improving Quality of Life on Cancer Patient by Implementation of Psychosexual Health Care)}

\author{
Yati Afiyanti*, Budi Ana Keliat**, Ida Ruwaida***, Imami Nur Rachmawati*, Nur Agustini**** \\ * Maternity \& Women's Health Nursing, Faculty of Nursing, University of Indonesia \\ **Psychiatric Nursing, Faculty of Nursing, University of Indonesia \\ ***Faculty of Sociology, University of Indonesia \\ ****Child Nursing, Faculty of Nursing, University of Indonesia, Indonesia \\ Email: yatikris@ui.ac.id
}

\begin{abstract}
ABSTRAK
Pendahuluan. Kontribusi perawat dalam meningkatkan kualitas hidup pasien kanker menyebabkan perawat harus memiliki pengetahuan dan ketrampilan dalam memberikan asuhan keperawatan dalam aspek kesehatan psikoseksual. Pelatihan perawatan kesehatan psikoseksual telah dikembangkan, diimplementasikan, dan diberikan kepada perawat onkologi di Indonesia untuk memenuhi kebutuhan tersebut sehingga perawat dapat memberikan perawatan kesehatan psikoseksual terhadap penderita kanker dan pasangannya. Metode. Pelatihan menggunakan metode pre dan post test untuk mengidentifikasi hasil serta perubahan skor dalam mengevaluasi pengetahuan, keyakinan, tindakan, kepercayaan diri dari peserta sebelum dan setelah pelatihan. Hasil. Pelatihan diberikan pada 46 perawat onkologi di Indonesia. Setelah pelatihan dan pendampingan didapatkan perubahan yang signifikan pada pengetahuan, keyakinan, kepercayaan diri dalam memberikan perawatan kesehatan psikoseksual pada pasien kanker dan pasangannya, namun tidak terdapat perbedaan yang signifikan pada aspek tindakan. Diskusi. Pelatihan tersebut telah menjadi standar asuhan keperawatan di Indonesia untuk perawatan pasien kanker dan telah menunjukkan bukti yang ilmiah bahwa perawat memang berkontribusi dalam meningkatkan kualitas hidup pasien kanker dengan memberikan asuhan keperawatan yang komprehensif melalui implementasi perawatan kesehatan psikoseksual pada pasien kanker dan pasangannya.
\end{abstract}

Kata kunci: perawatan kesehatan psikoseksual, pelatihan, keperawatan, kanker

\begin{abstract}
Introduction: The contribution of nurses in improving the quality of life of patients with cancer has caused them to have needs of getting knowledge and skills to provide services on psychosexual health care. Training on psychosexual health care has been developed, implemented and given to oncology nurses in Indonesia in order to fulfill the needs so that the nurses are able to provide psychosexual health care to cancer survivors and their spouse. Method: The training utilized a method of pre-and post-test evaluation to identify outcomes including changes of evaluation scores of knowledge, belief, practice, and self-efficacy of trainees before and after receiving psychosexual health care training. Result: The training has been implemented on 46 oncology nurses in Indonesia so that they can have knowledge, practice, belief and self-efficacy in providing psychosexual health care to patients with cancer and their spouse. After training and mentorship had been provided, there were significant changes on knowledge, belief and self-efficacy in providing psychosexual health care services to patients with cancer and their spouse; however, there were no significant changes on practices. Discussion: The training has become a standard nursing care for cancer in Indonesia and has provided scientific evidences that nurses have contribution in improving quality of life of patients with cancer by providing a comprehensive nursing care through implementation of psychosexual health care in their daily nursing care for patients with cancer and their spouse.
\end{abstract}

Keywords: Psychosexual health care, training, nursing, cancer

\section{INTRODUCTION}

Cancer may affect the quality of life of patients with cancer. Various physical, psychological and sexual problems may be encountered by patients with cancer, either caused by the diagnosis of cancer itself or as a result of cancer therapy. Psychosexual problems may give bad impacts of diminished social relationship of the patients with their family, spouse and community. For example, some studies on various experiences of cervical cancer survivors reported that the survivors had experienced various psychosexual problems, which caused bad impact on their quality of life (Greenwald \& McCorkle 2007; Klee, M. et al. 2000; Wenzel, L. 2005; Burns et al. 2007). The patients' social life including the intimacy with their spouse and playing the role as housewives, which is no longer perfect may bring risk of role dysfunction and may jeopardize family life.

The problems are not easy to be solved by the patients themselves or by the 
cancer survivors and their spouse. They need nurses and other health care personnel to manage psychosexual problems during and following cancer treatment (Hughes 2009; P.T et al. 2003). Survivors of cervical cancers and their spouse need help from health care personnel, especially nurses, to overcome the problems (Gamel et al. 2000; Afiyanti \& Milanti 2013; Powell et al. 2008; De Groot 2005).

Providing psychosexual health care is one of important roles for nurses who work at a cancer unit. Nurses play active roles to provide assistance in managing psychosexual problems in patients with cancer. The role of nurses in providing psychosexual services including developing a professional trust to empower the patients so that they can discuss their sexual problems, performing sexual evaluation review, managing sexual counseling as well as providing information and emotional support (Higgins et al. 2006; S \& Yoder 2009; Risen 1995; Moore \& Higgins 2009). Nevertheless, there is only a small number of nurses who have contributed their assistance on psychosexual problems in patients with cancer (Kautz et al. 1990; Gamel et al. 1995; Cort 1998; Guthrie 1999; Butler \& Banfield 2001; Magnan et al. 2005), including the nurses for cancer patients in Indonesia.

Most nurses have various obstacles to provide health care services associated with psychosexual problems. Various studies reported that nurses have limitations on knowledge and communication skills to discuss psychosexual problems; moreover, they also have lack of knowledge on the sexuality concept. An interview with some nurses has identified that no nurse has optimally provided education and counseling in managing psychosexual health problem of patients following the cancer treatment. Even if they did have given some explanation about it, the explanation was only a brief message to the patients.

Various problems such as lack of knowledge and skills about sexual education and counseling, reluctance on promoting sexual health, shyness to talk about sexuality and a taboo culture to have discussion about sex are obstacles for oncology nurses in Indonesia to provide a holistic nursing care for patients with cancer. Nurses need to be provided with knowledge and skills so that they can offer their assistance for cancer survivors and their spouse (Personal communication with Oncology nurses, October, 2013).

Similar problem has also been reported by previous studies, which reported that the nurses felt embarrassed and uncomfortable when discussing sexual issues with their patients and they did not have knowledge to provide counseling on sexual problems (Gamel et al. 1995; Cort 1998; Guthrie 1999; Magnan et al. 2005; Tsai 2004). Due to such limitations, many nurses have inappropriate perception on sexuality concept and assume that sexual problems are not important to be discussed and they do not feel comfortable to discuss sexual problems with the patients (Kotronoulas, G et al. 2009; Quinn 2003; Stead et al. 2003; Hughes 2009; Hautamaki et al. 2007).

Nursing interventions have been developed overseas to provide assistance in managing psychosexual problems. The interventions include sexual counseling, providing information on sexual health, sexual education and rehabilitation for patients with heart diseases and standard sexual health care services to help overcoming sexual problems and promoting health sex for patients with cancer and those with heart diseases (Gamel et al. 2000; Maughan \& Clarke 2001; Wilson \& Williams 1988; Webb 1988; Shuman \& Bohachuck 1987). A pilot study conducted by Joint Board of Clinical Nursing Studies has also successfully hold a kind of training associated with principles of psychosexual counseling for nurses and midwives, which aimed to train nurses and midwives to identify and provide constructive responses on various psychosexual issues of their patients in their daily practices (Irwin 2006). While in Indonesia, no training was available to train nurses that enable them to perform an evaluation or intervention to manage psychosexual problems of their patients. Such training is necessary for oncology nurses in Indonesia so that they can have a contribution to provide assistance in managing psychosexual problems of their patients (Personal communication with My, Dw, An, Yt, and M, Oncology nurses, October, 2013).

Moreover, there is lack of knowledge and practice by oncology nurses in Indonesia regarding psychosexual problems experienced by cancer survivors. It can restrain the development of researches and applied 
clinical practice of psychosexual health care in Indonesia. Until now, nursing care in Indonesia has no standard health care services to promote psychosexual health care services for patients; therefore, comprehensive nursing care conducted by nurses in Indonesia has not been optimal.

This article focuses on evaluation of psychosexual health care training, which has been developed, implemented and given to oncology nurses so that they are able to provide psychosexual health care service to help cancer survivors and their spouse to overcome their psychosexual problems. Training materials, various activities during the training and the results of training are explained in this article, including discussion and various implication of nursing care associated with the results of training.

\section{MATERIALS AND METHOD}

\section{Approaches and Development on Psychosexual Health Care}

Psychosexual aspect and its various problems has been identified as one of components in nursing care in the area of cancer nursing care. A holistic nursing care incorporates giving concern on psychosexual aspects for patients and their spouse. Psychosexual health care services provided by a nurse may include performing evaluation on sexuality aspects, establishing diagnosis on sexuality problem, providing interventions on psychosexual problems and evaluating outcomes of interventions on sexuality problems. As health care personnel who provide a holistic / comprehensive care for the patients, nurses should have knowledge and understanding about psychological and sexual aspects of their patients who have cancer. They should identify information of various available sources, applying standard of practice and developing clinical skill to provide routine questions in association with psychosexual aspects of their clients when performing clinical assessment.

Providing intervention of psychosexual nursing care has been proven empirically to give improvement on psychosexual problems as complained by the cancer survivors. It has been reported by previous studies that providing intervention of sexual education and counseling following cancer treatment can reduce psychosexual problems and may improve harmonic relationship / the relationship of the patients or survivors with their spouse following cancer treatment. (Afiyanti et al. 2011; Jeffries. S.A. et al. 2006; Powell et al. 2008).

Psychosexual health care provides supports for patients and their spouse through empowerment program so that they can discuss their psychosexual problem. The service also provides information for education, emotional supports, specific counseling to manage sexual dysfunction due to side effects of cancer treatment, helping patients and their spouse to adapt against physical and psychological changes and restoring the belief for women following cancer treatment (Jun et al. 2011; Moore \& Higgins 2009). Information, education and counseling on improving sexual health have become something that needed by patients and their spouse following cancer treatment. It has been proven by a study conducted by (De Groot 2005; Jun et al. 2011) reported that patients and their spouse needed explanation about improved sexual relationship following cancer treatment. Other studies have provided scientific evidences that intervention on counseling education may improve complaints of sexual dysfunction, reducing anxiety and depression, which finally may lead to increased quality of life in women following treatment of cervical cancer (Brotto et al. 2008; Powell et al. 2008).

A cross-sectional study evaluating perception of nurses about their roles on promoting sexual health (Butler \& Banfield 2001) reported that the majority of nurses suggested that sexuality is a part of practice in nursing care; although their knowledge, belief and responsibility have not fully reflected those issues. About $65 \%$ of them have played their role in discussing sexual health and only $15 \%$ have reported that they have never provided sexual health education to their patients. Investigators the study has affirmed their limitation of study associated with unrepresentative sample problem. Quinn (2003) in his study has found that the nurses admitted their lacking of experience, knowledge and skills in providing information and counselling for sexuality in patients with cancers. They indicated that they felt embarassed and fear to make mistakes in providing information on sexuality and cancer although the sexual review has already in 
complete format. While a study by Bruno (2003) demonstrated that about $61 \%$ nurses have never given any explanation about the effect of chemotherapy associated with the effect on reduced fertility. About $73 \%$ nurses did not explain the effect of chemotherapy on reduced sexual desire and early menopause symptoms as or following the effect of chemotherapy. Various obstacles had been mentioned by nurses in the study including lack of knowledge of the nurses on chemotherapy effect and the patients had never talked about sexual issues to the nurses.

\section{Psychosexual Health Care Training for Indonesian Nurses}

Psychosexual Health Care Training is a trial and part of applied Psychosexual Health Care Services model that will be continuously developed in further studies. The final outcome of the training is to produce skilled nurses in providing psychosexual nursing care. The aim of this training was to provide education on knowledge, belief, clinical practice and skills to increase for the nurses in providing practices on psychosexual health care so that they can share their contribution in increasing the quality of life of patients with cancer in Indonesia.

Furthermore, the objectives of the training were (1) to identify knowledge, belief, skills and self-efficacy of oncology nurse in managing psychosexual problems experienced by patients with cancer ; (2) to provide knowledge and to develop belief in order to establish psychosexual health care services ; (3) to practice clinical nursing skills and practice so that they can provide psychosexual health care services ; (4) to increase self-efficacy of the nurses in providing psychosexual health care services.

The method was competency-based training, i.e. the participants were expected to have competence for oncology nurses after completed the training including competence in providing psychosexual health care services. The process was performed by structured and group training thorugh interactive lectures, sharing nursing experiences, discussion, question and answer session, story-telling, training on communication skills, training on cases that had been proposed by the investigators, training on real cases (patients with cancer) and feed back bay trainers and facilitators. Moreover, after the training had been completed, a mentorship process was performed by facilitator and it was reevaluated to assess the clinical skills of participants after 3 weeks of training.

The material of training was presented in two modules developed by the investigators, i.e. a psychiatric nurse, a women's health nurse and a sociologist who has expertise in gender and women sexuality studies. The first module contained study material about Cancer, Psychosexual Problems and the Role of Nurses in Providing Psychosexual Health Care Services to Patients and Their Spouse. In addition, the second module contained material about Standard Nursing Care on Psychosexual Problem. The training was provided by the investigators. Training material was developed according to the need of nurses and it was referred to results of objective measurement on the first stage, which was enriched by additional material such as effective communication skills and techniques, the method of doing interview to discuss about sexuality topics, and the method of documenting services that had been given. PLISSIT model, which is a conceptual framework, was given in the training to teach participants about providing nursing intervention for sexual dysfunction problem. Utilization of PLISSIT model needs a right and appropriate interpersonal communication skills performed by the nurses. The model was developed by Annon (1974) which is more commonly known as the sexual counseling model. This model facilitates the discussion between nurses and their patients on sexual problems experienced by the patients. PLISSIT model has been widely and systematically utilized by health care personnel including general and specialized nurses to help their patients to overcome or at least to minimize sexual dysfunction problem and psychosocial problems of patients with cancer.

The trainings needed five days consisted of 6 class sessions or 3 lecture days and 4 sessions for practice, both in class through case simulation session or direct real cases; therefore, the total time needed for training was 35 hours. The trainings were performed in the class room, in the ward and outpatient clinic of each hospital where the participants were working. The media that have been used during training were module books containing training material and work books, which were used for training and evaluating the progress 
of nursing practice. In addition to the books, other media used for trainings were power point slides which had been prepared by the trainers and other supporting materials such as LCD, laptop, white board, writing board and flipchart paper. The activity of each session was initiated by sharing previous experiences, which were associated with the material and it was followed by explaining and discussing material through discussion session or question and answer sessions. The participant of trainings were obliged to practice their clinical skills through direct practice (at the last day of training) for a patient with cancer after the lectures and case simulation practices had been completed. The results of trainings were reported in their log book. The facilitators monitored the training process in the ward or outpatient clinics. Facilitators also helped participants when there was any problem during the training.

\section{Method}

This study was conducted to evaluate a psychosexual health care training which had been given to nurses by transferring the learning process of knowledge, practices, belief and self-efficacy to the participants of the training. The nurses were expected to perform nursing intervention in helping cancer survivors and their spouse so that they can overcome psychosexual problem. The training used evaluation method of pre- and post-test to find final outcome which included changes on evaluation scores of knowledge, belief, practice, and self-efficacy of the participants before and after psychosexual health care training. The outcome for knowledge was measured by knowledge test in multiple choice questions. The outcomes for belief, self-efficacy and practice were measured by self-reported scale, which were done during the training and within 3 weeks after training. This study also had been granted ethical clearance from Ethical Commission at Faculty of Medicine, University of Indonesia.

\section{Data collection}

Data collection was performed through trainings and mentorships between June and October 2013. Trainings and mentorships were hold at the hospital where the participant nurses were working. Participants of trainings were oncology nurses who provide nursing care for patients with cancer, either for those who were having treatment at the outpatient clinics or who were hospitalized in the wards. Participants of training filled in questionnaires containing questions about knowledge, belief, practice and self-efficacy about providing psychosexual health care services before participating in the training (pre-test). Furthermore, the questionnaires were filled in again after the trainings and mentorship (posttest). The training was conducted by three investigators; while mentorships were performed by facilitators that had been trained by the investigators team.

\section{Measurement}

Measurement of the nurses' knowledge in this study was developed from module material. The knowledge test contained of 13 items of multiple choice questions. Each item had 5 alternative answers and participants were asked to select the best answer for each question.

The measurement of belief was developed from The Sexual Attitudes and Beliefs Survey (SABS), which had been translated into Indonesian language. Question items for measuring the belief of training participants developed from the SABS item were modified by the investigator team into 14 questions. Training participants responded the belief items using a 5 point Likert scale with answer options of: Strongly disagree, Disagree, Neither agree nor disagree, Agree, Strongly Agree. The cronbach's alpha value of 0.70 . $(n=135)$.

The measurement of Self-Efficacy was evaluated using 5 question items developed by the investigators. The items of self-efficacy measured confidence state of participants in providing psychosexual health care services. An example of item for measuring selfefficacy: "I feel confident with my ability to discuss about patient's sexuality problem." Training participants responded the selfefficacy items using a 5 point Likert scale with answer options of: Strongly disagree, Disagree, Neither agree nor disagree, Agree, Strongly Agree.

The measurement of nursing practice was evaluated using 11 question items developed by the investigators. The question items about the practice measured daily nursing practice in providing nursing care associated with the presence or absence of evaluation and intervention on the patient's psychosexual 
problem. An example of item for measuring practices: "I provide opportunity for patients to talk about their sexuality problems," Training participants responded the practices items using a 5 point Likert scale with answer options of: Strongly disagree, Disagree, Neither agree nor disagree, Agree, Strongly Agree.

\section{Participants}

The inclusion criteria of participants who could take part in the training were those who had been working as oncology nurses for at least 2 years at an oncology unit and those who had education level of at least Diploma in nursing. About 46 cancer / oncology nurses from 3 hospitals specialized in cancer services in Jakarta had been participated in the training. The mean age of participants was at range of $31-50$ years and most of them were female nurses (91.3\%). About 54\% of participants had education level of nursing diploma and $87 \%$ of participants had working experiences of approximately 4 years, either as a general nurse or oncology nurse.

\section{RESULT}

Table 1. Characteristics of the participants $(\mathrm{N}=46)$

\begin{tabular}{lr}
\hline \multicolumn{1}{c}{ Variables } & $\%$ \\
\hline Age & 17.4 \\
\hline $20-30$ & 50.0 \\
\hline $31-40$ & 30.4 \\
\hline $41-50$ & 2.2 \\
\hline $51-55$ & 8.7 \\
\hline Sex & 91.3 \\
\hline Male & \\
\hline Female & 54.3 \\
\hline Levels of Nursing Education & 8.7 \\
\hline Diploma in Nursing & 37.0 \\
\hline Bachelor of Nursing & 13.0 \\
\hline Master of Science in Nursing & 87.0 \\
\hline Working experiences as a nurse & \\
\hline $1-4$ year(s) & 8.7 \\
\hline $4>$ years & 4.3 \\
\hline Working experiences as a nurse at a \\
Cancer Unit
\end{tabular}

Table 2 reports that there were significant statistical changes or increase of each measurement regarding knowledge, belief and self efficacy. However, no significant change had been found for the score of practices following the training.
The mean score on the aspect of participants' knowledge after training and mentorships was significantly higher (76.94 \pm 8.25) compared to before training (51.78 \pm 13.75). The $p$ value of 0.000 indicated that there was a significant difference of score changes regarding the nurses' knowledge before and after training on sexuality concept as well as on the method of doing evaluation and intervention for psychosexual health care services.

The mean score on the aspect of participant's belief in providing psychosexual health care services after training and mentorships was significantly higher (49.63 \pm 4.73) compared to before training (49.28 \pm 5.02). The $p$ value of 0.008 indicated that there was significant difference on score changes of the nurses' belief before and after training.

The mean score on the aspect of participant's selfefficacy after training and mentorship was significantly higher ( $14.76 \pm 2.64)$ compared to before training (14.43 \pm 2.79 ). The $p$ value of 0.000 indicated significant difference on score changes of the nurses' self-efficacy before and after training.

The mean score on the aspect of participant's practices after training and mentorship was significantly higher $(26.89 \pm 4.29)$ compared to before training (26.65 \pm 4.26 ). The $p$ value of 0.062 showed that there was no significant difference on score changes of the nurses' practice before and after training.

\section{DISCUSSION}

The study results reported that the psychosexual health care training has successfully transferred knowledge and trained the participants to have ability in providing psychosexual health care services for patients with cancer and their spouse. The study material included topics on cancer, psychosexual problems and the role of nurses in providing psychosexual health problem for patients and their spouse. It has successfully provided knowledge and affirmed belief for participants that they have professional role as nurses to manage psychosexual problems experienced by the patients with cancer.

Moreover, the activity of practicing standard nursing care to overcome the patients' psychosexual problems that had been given in the training has successfully increased self-efficacy and provided practice as well as experiences for the participants 
Table 2. Mean value of differences on Knowledge, Practices, Belief and Self-Efficacy Before and After Training $(\mathrm{n}=46)$

\begin{tabular}{lccccc}
\hline \multirow{2}{*}{ Variables } & \multicolumn{2}{c}{ Mean } & \multicolumn{2}{c}{ SD } & \\
\cline { 2 - 5 } & $\begin{array}{r}\text { Before } \\
\text { Trainin }\end{array}$ & $\begin{array}{c}\text { After } \\
\text { Trainin }\end{array}$ & $\begin{array}{c}\text { Before } \\
\text { Trainin€ }\end{array}$ & $\begin{array}{r}\text { After } \\
\text { Trainin }\end{array}$ & P value \\
\hline Belief & 49.28 & 49.63 & 5.02 & 4.73 & 0.008 \\
Practice & 26.65 & 26.89 & 4.26 & 4.29 & 0.062 \\
Self-efficacy & 14.43 & 14.76 & 2.79 & 2.64 & 0.017 \\
Nurses' Knowledg $\epsilon$ & 51.78 & 76.94 & 13.75 & 8.25 & 0.000 \\
\hline
\end{tabular}

when dealing with psychosexual problems of patients with cancer. Following the training, there were changes on measurements of knowledge, belief, and practice. Improved knowledge gives positive and significant effect to the participants to understand about the method of discussing and evaluating patients' psychosexual problems and how to provide psychosexual health care services.

Psychosexual problem is a sensitive problem; therefore the nurses' knowledge is necessary in evaluating and performing intervention against the patients' psychosexual problems, which should keep the patient's privacy; as well as earning the patient's trust and managing the problem without judging the patients (Mick et al. 2004; Mick 2007; Schain 1988). The participants had also learned communication skills or method of discussing sexuality problems with their patients such as how to practice empathy and provide motivation for their patients so that they can manage the psychosexual problem. Difficulty in discussing sexual problem is one of obstacles for nurses in providing a comprehensive nursing care for patients with cancer (Hautamaki et al. 2007; Hordern \& Street 2007). Therefore, in this training, the participants received knowledge and skills about how to discuss sexuality problems with their patients. Moreover, they also have received knowledge about providing intervention using PLISSIT model although to apply the model in daily practice, they still need to frequently use the mode in their daily practices with their other patients.

The aspect of belief should be hold by the nurses in discussing sexuality with their patients. The training affirmed the participants to hold on belief that sexuality problem is not a taboo to be discussed with the patients and they should believe that patients with cancer have sexuality problems that need assistance from their nurses to manage the problem.
Moreover, the training participants of this study have also focused to hold a belief that evaluating and discussing the patients' sexual problems is part of their professional role and responsible as nurses. As has been mentioned by many experts in nursing care, helping patients to discuss their sexual problems is part of the nurses' role to provide a holistic nursing care, including recognizing other various psychosexual issues experienced by patients with cancer and their spouse (Royal College of Nursing 2000; Higgins et al. 2006; S \& Yoder 2009; Irwin 2006; Haboubi \& Lincoln 2003).

Furthermore, on the aspect of selfefficacy, the participants have also shown improvement. After the training, the participants had good confidence to discuss about their patient's sexuality problem and did not encounter any difficulty in discussing psychosexual problems with their patients. However, the participants have not shown significant results on score of clinical practice and skills after the training. This may occur since the participants had not been used to the techniques and they still need time to apply their various knowledge and skills from the training into their daily practice when providing nursing care for patients with cancer.

In general, this training may fulfill the needs of participants to acquire knowledge, belief, self-efficacy and practice in providing psychosexual health care services, which have been regarded as a taboo and uncomfortable topic to be discussed with the patients. Improved knowledge, practice and selfefficacy and improved belief of the nurses in providing psychosexual health care services after having training and mentorship may contribute to increase quality of life of the patients and their spouse by providing the necessary psychosexual health care services for the patients with cancer and their spouse. 
The results of training in this study may become the means in giving knowledge, belief and skills for oncology nurses in Indonesia as a contribution to provide psychosexual health care services for patients with cancer. Evaluation of the training may become one of applied psychosexual health care services in clinical setting of oncology nursing care in Indonesia.

Moreover, the results of the training may become a prototype model for applied nursing care in Indonesia to achieve national standard in health care services in promoting psychosexual health care problems for cancer patients and survivors so that the nurses can provide a comprehensive nursing care to increase the quality of life of patients with cancer. By participating in the training, the participants acquire knowledge and skills to discuss sexual problems with their patients and hold on a belief that performing psychosexual evaluation and intervention is a part of professional roles of the nurses that should be implemented in daily nursing practice.

\section{CONCLUSIONANDRECOMMENDATION}

\section{Conclusion}

The results of this study have found effectiveness of training and mentorship for psychosexual health care services as had been participated by 46 nurses of three hospitals providing services for patients with cancer. Oncology nurses have a special position to provide psychosexual education and counseling to increase the quality of life of cancer patients and survivors.

\section{Recommendation}

Something essential should be applied in daily nursing practice, i.e. the nurses need to evaluate and perform intervention on psychosexual problems of patients with cancer at the beginning of interaction by giving permission to every patient with cancer to have comfortable discussion on their psychosexual problems. The results of this training may be adapted as a standard of practice on providing psychosexual health care services in Indonesia, particularly in the subject of cancer nursing care.

\section{REFERENCES}

Afiyanti, Y., Andrijono \& D Gayatri, 2011.
Perubahan keluhan seksual fisik dan psikologis pada perempuan pascaterapi kanker serviks setelah intervensi keperawatan. Jurnal Ners, 6(1), pp.6875.

Afiyanti, Y. \& Milanti, A., 2013. Physical sexual and intimate relationship concerns among Indonesian cervical cancer survivors: A phenomenological study. Nursing and Health Sciences, 15(2), pp.151-156.

Annon, J., 1974. The PLISSIT model: A proposed conceptual scheme for the behavioral treatment of sexual problems. Journal of Sex Education Therapy, 2(1), pp.1-15.

Brotto, L.A. et al., 2008. A psychoeducational intervention for sexual dysfunction in women with gynecologic cancer 10th ed.,

Burns, M. et al., 2007. Assessing the impact of late treatment effects in cervical cancer: an exploratory study of women's sexuality. European Journal of Cancer Care, 16, pp.364-372.

Butler, L. \& Banfield, V., 2001. Oncology nurses's views on the provision of sexual health in cancer care. Journal of Reproductive Medicine, 1(1), pp.35-39.

Cort, E., 1998. Nurses' attitudes to sexuality in caring for cancer patients. Nursing Times, 94, pp.54-56.

Gamel, C. et al., 1995. Factors that influence the provision of sexual health care by Dutch cancer nurses. International Journal of Nursing Studies, 32(3), pp.301-314.

Gamel, C., Hengeveld, M. \& Davis, B., 2000. Informational needs about the effects of gynaecological cancer on sexuality: a review of the literature. Journal of Clinical Nursing, 9, pp.678-688.

Greenwald, H.P. \& McCorkle, R., 2007. Remedies life change among invasive cervical cancer survivor. Urology Nursing, 27(1), p.47-53.

De Groot, et. al, 2005. The psychosocial impact of cervical cancer among affected women and their partners. International Journal of Gynecological Cancer, 15(5), pp.918-925.

Guthrie, C., 1999. Nurses' perceptions of sexuality relating to patient care. Journal of Clinical Nursing, 8(3), pp.313-321.

Haboubi, N.H. \& Lincoln, N., 2003. Views of 
health professionals on discussing sexual issues with patients. Disability and Rehabilitation, 25(6), pp.477-482.

Hautamaki, K. et al., 2007. Opening communication with cancer patients about sexuality-related issues. Cancer Nursing, 30(5), pp.399-404.

Higgins, A., Barker, P. \& Begley, C., 2006. Sexuality: the challenge to espoused holistic care. International Journal of Nursing Practice, 12(6), pp.345-51.

Hordern, A.J. \& Street, A.F., 2007. Communication about patient sexuality and intimacy after cancer: Mismatched expectations and unmet needs. Medical Journal of Australia, 186(5), pp.224227.

Hughes, M.K., 2009. Sexuality and cancer: The final Frontier for Nurses. Oncology Nursing Forum, 36(5), pp.241-246.

Irwin, R., 2006. Review paper: Thirty years of psychosexual nursing. Sexual and Relationship Therapy, 21(4), pp.445461.

Jeffries. S.A. et al., 2006. An effective group psychoeducational intervention for improving compliance with vaginal dilation: a randomised kelompok non intervensiled trial. International Journal Radiation Oncology Biology Physics, 5, pp.404-411.

Jun, E.Y. et al., 2011. The effect of a sexual life reframing program on marital intimacy, body image, and sexual function among breast cancer survivors. Cancer Nursing, 34(2), pp.142-149.

Kautz, D.D., Dickey, C.A. \& Stevens, M.N., 1990. Using research to identify why nurses do not meet established sexuality nursing care standards. Journal of Nursing Quality Assurance, 4(3), pp.6769.

Klee, M., Thranov, I. \& Machin, D., 2000. Life after radiotherapy: The psychological and social effects experienced by women treated for advanced stages of cervical cancer. Gynecologic Oncology, 76., pp.5-13.

Kotronoulas, G, Papadopoulou, C. \& Patiraki, E., 2009. Nurses's knowledge, attitudes, and practices reganding provision of sexual health care in patients with cancer: critical review of the evidence. Supportive Care Cancer, 17(5), pp.479501.
Magnan, M.A., Reynolds, K.E. \& Galvin, E.A., 2005. Barriers to addressing patient sexuality in nursing practice. Medical-Surgical Nursing, 14(5), pp.282-290.

Maughan, K. \& Clarke, C., 2001. The effect of a clinical nurse specialist in gynaecology oncology on quality of life and sexuality. Journal of Clinical Nursing, 10(2), pp.221-229.

Mick, J., Hughes, M. \& Cohen, M.Z., 2004. Using BETTER Model to assess sexuality. Clinical Journal of Oncology Nursing, 8(1), pp.84-86.

Mick, J.M., 2007. Sexuality assessment: 10 strategies for improvement. Clinical Journal of Oncology Nursing, 11(5), pp.671-675.

Moore, A.M. \& Higgins, A., 2009. Testicular cancer: exploring the psychosexual issues. British Journal of Nursing, 18(19), pp.1182-1186.

P.T, J. et al., 2003. Early stage cervical carcinoma, radical hysterectomy and sexual function. Cancer, 100(1), pp.97106.

Powell, C.B. et al., 2008. A randomized study of the effectiveness of a brief psychosocial intervention for women attending a gynecologic cancer clinic. Gynecologic Oncology, 111, pp.137143.

Quinn, B., 2003. Sexual health in nursing care. Nursing Times, 99(4), pp.32-34.

Risen, C.B., 1995. A guide to taking a sexual history. Psychiatric Clinics of North America, 18(1), pp.39-53.

Royal College of Nursing, 2000. Sexuality and Sexual Health in Nursing Practice, London.

S, B. \& Yoder, L., 2009. The medical-surgical nurse's guide to testicular cancer. Medical-Surgical Nursing, 18(2), pp.116-123.

Schain, W., 1988. A sexual interview is a sexual intervention. Innovations in Oncology Nursing, 4(4), pp.2-3.15.

Shuman, N.A. \& Bohachuck, P., 1987. Nurses' attitudes towards sexual counseling. Dimensions in Critical Care Nursing, 6(2), pp.75-81.

Stead, M.L. et al., 2003. Lack of communication between healthcare professionals and women with ovarian cancer about sexual issues. British 
Journal of Cancer, 88(5), pp.666-671. Available at: http://www.nature.com/doifinder/10.103 8/sj.bjc.6600799.

Tsai, Y.G., 2004. Nurses facilitators and barriers for taking a sexual history in Taiwan. Applied Nursing Research, 17(4), pp.257-64.

Webb, C., 1988. A study of nurses's knowledge and attitudes about sexuality in health care. International Journal of Nursing Studies, 16(6), pp.677-688.

Wenzel, L., et. al., 2005. Quality of life in long-term cancer survivors. Gynecologic Oncology, 97, pp.310-317.

Wilson, M.E. \& Williams, H.A., 1988. Oncology nurses' attitudes and behaviours related to sexuality of patients with cancer. Oncology Nursing Forum, 15, pp.49-53. 